\title{
ANALISIS ASAM RETINOAT PADA KRIM PEMUTIH MALAM YANG BEREDAR DI KLINIK KECANTIKAN KOTA JAMBI PADA KECAMATAN JELUTUNG
}

\author{
RETINOID ACID ANALYSIS OF NIGHT BLEACHING CREAM \\ CIRCULATING BEAUTIFUL CLINIC BEAUTY OF JAMBI CITY IN \\ JELUTUNG DISTRICT
}

\author{
Armini Hadriyati, Barmi Hartesi*, Siska Fitri \\ Program Studi Farmasi Sekolah Tinggi Ilmu Kesehatan Harapan Ibu Jambi \\ *Penulis Korespodensi, e-mail: barmi.hartesi@gmail.com
}

\begin{abstract}
ABSTRAK
Salah satu bahan pemutih berbahaya yang ditakutkan terdapat dalam krim adalah asam retinoat karena asam retinoat dapat menyebabkan kulit kering, rasa terbakar, teratogenik (cacat pada janin), dan menyebabkan kanker kulit. Tujuan penelitian ini untuk mengetahui apakah krim pemutih yang beredar di kecamatan Jelutung kota Jambi mengandung asam retinoat serta untuk mengetahui berapa kadar asam retinoat yang terkandung dalam krim pemutih wajah tersebut. Metode yang digunakan untuk analisis asam retinoat pada krim pemutih menggunakan kromotografi cair kinerja tinggi fase terbalik. Hasil uji validasi menunjukkan nilai RSD 0,4887 \%, parameter linearitas $\mathrm{r}=0,9982$, LOD 0,0468 ppm, LOQ 1,565 ppm. Hasil analisa kuantitatif kandungan asam retinoat pada krim $1(0,032 \%)$, krim $2(0,015 \%)$, krim $3(0,014 \%)$ krim $4(0,016 \%)$ dan krim $5(0,011 \%)$. Berdasarkan persyaratan dari BPOM krim pemutih tidah boleh mengandung asam retinoat. Berdasarkan hasil penelitian dapat disimpulkan bahwa krim pemutih wajah yang beredar di kecamatan Jelutung kota Jambi mengandung asam retinoat.
\end{abstract}

Kata kunci : asam retinoat, krim pemutih, metode KCKT

\section{ABSTRACT}

One of the harmful bleaching ingredients is retinoic acid because it can cause dry skin, burning, teratogenic (defect in the fetus), and causing skin cancer. The purpose of this study was to determine whether whitening creams that circulating in Jambi in Jelutung district containing retinoic acid as also to determine the levels of retinoic acid contained in the face whitening cream. The result of validation showed that $R S D$ value $0.4887 \%$, parameter of linearity $r=0.9982$, , LOD $0.0468 \mathrm{ppm}$, LOQ $1.565 \mathrm{ppm}$. The results of quantitative analysis of retinoic acid content in cream $1(0.032 \%)$ cream 2 $(0.015 \%)$, cream $3(0.014 \%)$ cream $4(0.016 \%)$ and cream $5(0.011 \%)$. Based on the requirements of BPOM, whitening cream may not contain acid retinoat. Based on the results of the above research it can be concluded that the face whitening cream that circulates in the city of Jambi in Jelutung district contains retinoic acid. 
Keywords: retinoic acid, whitening cream, HPLC method

\section{PENDAHULUAN}

Sediaan kosmetik merupakan salah satu bagian dari sediaan farmasetika. Kosmetik berperan penting untuk menunjang penampilan seseorang, bahkan bagi masyarakat tertentu kosmetik sudah menjadi kebutuhan pokok seperti halnya sandang dan pangan. Umumnya, di pasaran banyak beredar sediaan kosmetika yang berperan untuk keindahan kulit wajah. Dalam perkembangan selanjutnya, suatu sediaan kosmetika akan ditambahkan suatu zat ikatan atau tambahan yang akan menambah nilai artistik dan daya jual produknya, salah satunya dengan penambahan bahan pemutih yang berbahaya bagi konsumen (Anggraeni et al., 2018).

Menurut BPOM RI No. HK. 00. 05. 42. 1018 Tahun 2008 asam retinoat juga termasuk yang penggunaannya dilarang pada sediaan kosmetik dikarenakan dapat menyebabkan kulit kering, rasa terbakar, dan teratogenik (cacat pada janin). Asam retinoat ini sering dipakai sebagai bentuk sediaan vitamin A topikal, yang hanya dapat diperoleh dengan resep dokter. Banyak produk yang kini beredar di pasaran mengandung beberapa zat yang tidak memenuhi syarat kelayakan pemakaian (Suhartini et al., 2013).

Kasus yang memperkuat dilarangnya asam retinoat dalam sediaan kosmetik yaitu Waugh (2004) telah melaporkan bahwa bayi yang terlahir dari seorang wanita yang mengoleskan asam retinoat dengan kadar $0,05 \%$ sebanyak dua kali sehari untuk wajah berjerawat, sebelum dan selama kehamilan, mengalami malformasi berat pada wajah seperti kecacatan langit-langit mulut, bibir sumbing, celah kelopak mata menyatu, hipertelorisma, defisiensi lubang hidung kiri dan kelainan sistem saraf pusat serta hidrosefalus. Kasus lainnya melibatkan seorang wanita yang telah menggunakan krim asam retinoat dengan kadar $0,05 \%$ selama sebulan sebelum menstruasi terakhir dan selama sebelas minggu pertama kehamilan, dilaporkan bahwa bayi yang terlahir mengalami cacat telinga eksternal (Septadina, 2012).

Adanya larangan penggunaan asam retinoat pada kosmetik dari BPOM dan mengetahui bahayanya penggunaan asam retinoat pada kosmetik maka penulis ingin melakukan penelitian ini untuk mengetahui krim pemutih yang beredar di kota Jambi mengandung asam retinoat atau tidak dan untuk melihat berapa kadar asam retinoat 
pada krim pemutih wajah yang beredar di Kota Jambi menggunakan metode kromatografi cair kinerja tinggi .

\section{METODE PENELITIAN}

\section{Alat dan Bahan}

Alat penelitian yang digunakan adalah seperangkat alat KCKT LC-6AD $\left(\right.$ SHIMADZU $\left.^{\circledR}\right)$, yang dilengkapi detektor UV-Vis (Ultraviolet-Visibel SPD M20A), kolom C18 (Oktadesil Silane) $15 \mathrm{~cm}$ x 4,6 mm, ukuran partikel $10 \mu \mathrm{m}$. Sentrifugator, glass ware, Erlenmeyer $\left(\operatorname{Iwaki}^{\circledR}\right)$, gelas ukur (Iwaki $\left.{ }^{\circledR}\right)$ ), batang pengaduk, spatel, tissue, lemari pendingin $\left(\mathrm{LG}^{\circledR}\right)$, timbangan analitik (precisa XB 220A ${ }^{\circledR}$ ), oven $\left(\mathrm{MEMMERT}^{\circledR}\right.$ ), sonikator, vortex mixer, gelas objek dan $\mathrm{pH}$ meter.

Bahan yang digunakan adalah baku pembanding asam retinoat, aqua bidestilasi, asetonitrit, asam fosfat dan sampel krim pemutih yang diduga mengandung asam retinoat yang dijual di klinik dan salon kecantikan kecamatan Jelutung kota Jambi.

\section{Jalannya Penelitian}

\section{Validasi metode analisis}

Kurva baku asam retinoat

Larutan baku asam retinoat konsentrasi 10 ppm dipipet sebanyak 2, 4, 6, 8, 10 $\mathrm{mL}$, masing-masing dimasukkan ke dalam labu takar $10 \mathrm{~mL}$ dan ditambahkan asetonitril sampai tanda batas lalu disonikasi selama 1-2 menit untuk menghilangkan gelembung udara. Larutan dengan konsentrasi 2,4, 6, 8, $10 \mathrm{~mL}$ disuntikkan sebanyak 20 $\mu \mathrm{L}$ ke alat KCKT dengan kecepatan alir 1,4 mL/menit. Lalu dicatat luas puncaknya yang ditunjukkan pada kromatogram dan dibuat kurva baku serta persamaan regresi liniernya (Rahayu, 2014).

Presisi

Larutan baku asam retinoat konsentrasi 10 ppm dipipet sebanyak $6 \mathrm{~mL}$ lalu dimasukkan ke dalam labu takar $10 \mathrm{~mL}$ dan ditambahkan asetonitril sampai tanda. Larutan baku asam retinoat dengan konsentrasi 6 ppm disuntikkan sebanyak $20 \mu \mathrm{L}$ ke dalam alat KCKT. Luas area yang diperoleh dicatat kemudian ditentukan koefisien variasinya (Rahayu, 2014). 
Akurasi

Pada pengujian akurasi tidak menggunakan larutan baku asam retinoat. Sampel krim pemutih ditimbang sebanyak $250 \mathrm{mg}$ kemudian dimasukkan ke dalam tabung sentrifus. Asetonitril sebanyak $10 \mathrm{~mL}$ ditambahkan dan dicampur menggunakan vortex mixer selama 5 menit. Kemudian dipipet sebanyak $1 \mathrm{~mL}$ larutan dan dimasukkan dalam labu takar $5 \mathrm{~mL}$, setelah itu ditambahkan asetonitril hingga garis batas (Rahayu, 2014).

\section{Penetapan kadar sampel}

Sampel krim pemutih ditimbang sebanyak 250 mg kemudian dilarutkan dengan $10 \mathrm{ml}$ asetonitril lalu divortex mixer selama 5 menit agar tercampur dengan baik. Disentrifuge dengan kecepatan $600 \mathrm{rpm}$ selama 10 menit. Sampel dianalisis dengan menggunakan KCKT fase terbalik. Larutan yang disuntikkan sebanyak $20 \mu \mathrm{L}$ dengan kecepatan alir fase gerak 1,4 mL/menit dan dicatat kadarnya. Percobaan diulang 3 kali (Rahayu, 2014).

\section{Evaluasi Krim}

Uji stabilitas

Pengamatan pada 5 krim pemutih malam yang diambil di 4 klinik kecantikan dan 1 salon untuk melihat pengaruh suhu terhadap krim selama penyimpanan pada beberapa suhu yang berbeda yaitu pada suhu $4^{\circ} \mathrm{C}$, suhu ruangan, dan suhu $45^{\circ} \mathrm{C}$ selama 28 hari. Setiap 7 hari dilakukan pengujian organoleptis, pengukuran $\mathrm{pH}$, uji daya sebar dan uji homogenitas dilihat setiap hari (Kurniasih, 2016).

Uji organoleptis

Pengamatan organoleptis meliputi bentuk, warna, dan aroma yang diamati secara objektif. Pengamatan ini bertujuan untuk melihat terjadinya perubahan secara signifikan pada sediaan yang telah dibuat (Yulianti, et al., 2015).

Uji homogenitas

Pemeriksaan homogenitas dilakukan dengan menggunakan gelas objek. Caranya: sejumlah krim dioleskan pada sekeping kaca atau object glass menghasilkan sediaan yang homogen dan tidak terlihat butiran - butiran kasar (Kurniasih, 2016). 
Pengukuran $\mathrm{pH}$

Pemeriksaan $\mathrm{pH}$ dilakukan dengan menggunakan $\mathrm{pH}$ meter. Pemeriksaan dilakukan dengan mencelupkan elektroda ke dalam 1 gram krim yang telah diencerkan dengan menggunakan aquadest $10 \mathrm{~mL}$. Produk kosmetika sebaiknya dibuat sesuai dengan pH kulit dengan rentang 4,5-7 (Puspitasari et al., 2018).

Uji daya sebar

Sebanyak 1 gram krim ditimbang kemudian diletakkan di tengah-tengah plastik transparan yang di bawahnya terdapat kertas grafik, kemudian ditutup dengan plastik lain yang telah ditimbang beratnya terlebih dahulu, didiamkan selama 1 menit. Kemudian diukur diameter sebar sampel. Setelah itu ditambah beban dengan berat 2 gram dan didiamkan selama 1 menit, kemudian diukur diameter sebarnya. Dilakukan perlakuan yang sama secara terus-menerus pada beban 4 dan 6 gram, kemudian diukur (Ismail, et al., 2014).

\section{Uji iritasi}

Krim ditimbang sebanyak 0,1 g lalu dioleskan pada bagian dalam lengan kemudian dibiarkan selama 24 jam dan dilihat perubahan yang terjadi berupa gatal, kemerahan dan pengkasaran pada kulit. Uji iritasi dilakukan untuk masing-masing formula pada 10 orang sukarelawan (Suhery et al., 2016).

\section{HASIL DAN PEMBAHASAN}

\section{Hasil validasi dan penetapan kadar asam retinoat}

Pada kurva kalibrasi (Gambar 1) diperoleh persamaan regresi linier $\mathrm{y}=53507 \mathrm{x}-$ 9701 dengan koefisien kolerasi $(r)=0,9982$. Dari perolehan koefisien korelasi dapat disimpulkan bahwa analisis asam retinoat dalam rentang $2-10$ ppm merupakan analisis yang valid dan memenuhi syarat linieritas karena nilai $r$ yang mendekati angka 1 menunjukkan hubungan linear yang baik antara konsentrasi dengan luas area. Penetapan kadar dengan kurva kalibrasi terjamin kebenarannya (Miller and Miller, 2005). 


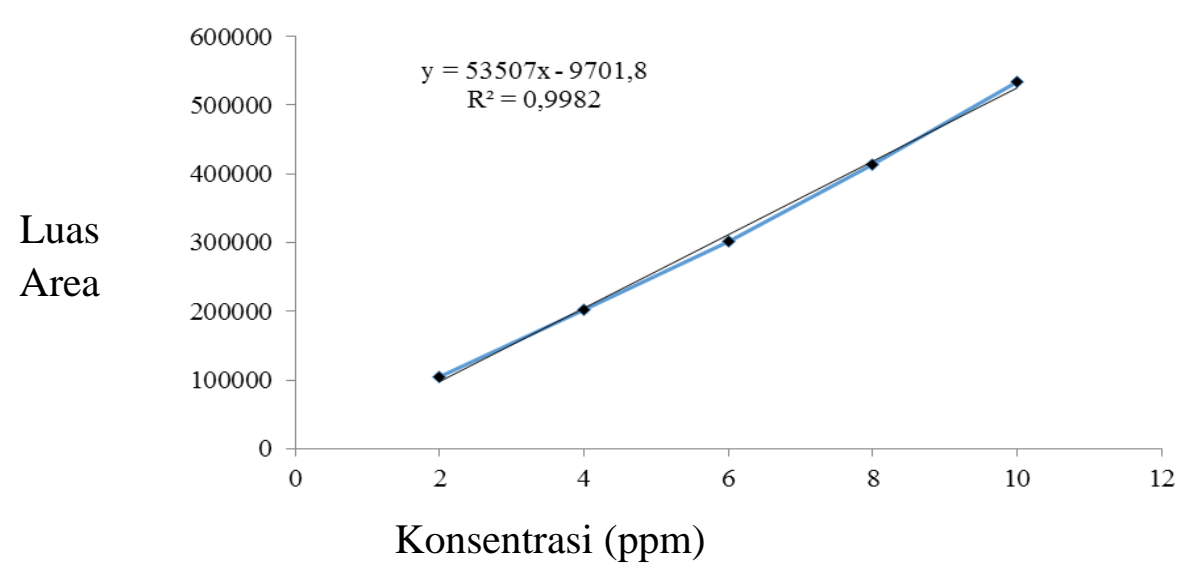

Gambar 1. Kurva kalibrasi asam retinoat

Untuk mendapatkan hasil analisis yang baik dilakukan optimasi terlebih dahulu untuk untuk mencari kondisi optimal. Uji kesesuaian sistem bertujuan untuk memastikan sistem operasi secara lengkap mulai dari instrumen, reagen, dan kolom telah cocok untuk penggunaannya. Dari kromatogram yang diperoleh dilakukan pengamatan terhadap waktu retensi asam retinoat, pada tiga perbandingan komposisi fase gerak. Dari ketiga kondisi tersebut kondisi yang paling baik adalah dengan perbandingan asetonitril : asam fosfat $0,2 \%$ (90:10) dengan puncak asam retinoat 15,587 menit dapat dilihat pada (Gambar 2 dan Gambar 3). Dua perbandingan lain tidak dipilih karena pada puncaknya masih dipengaruhi oleh banyak pengotor dan pelarut.

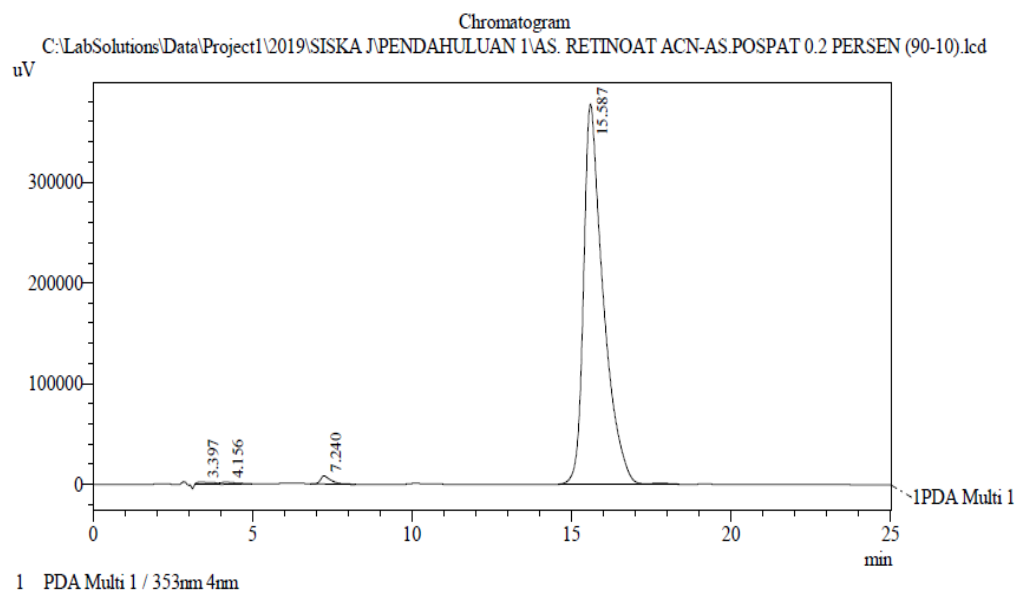

Konsentrasi (ppm)

Gambar 2. Kromatogram optimasi baku asam retinoat 


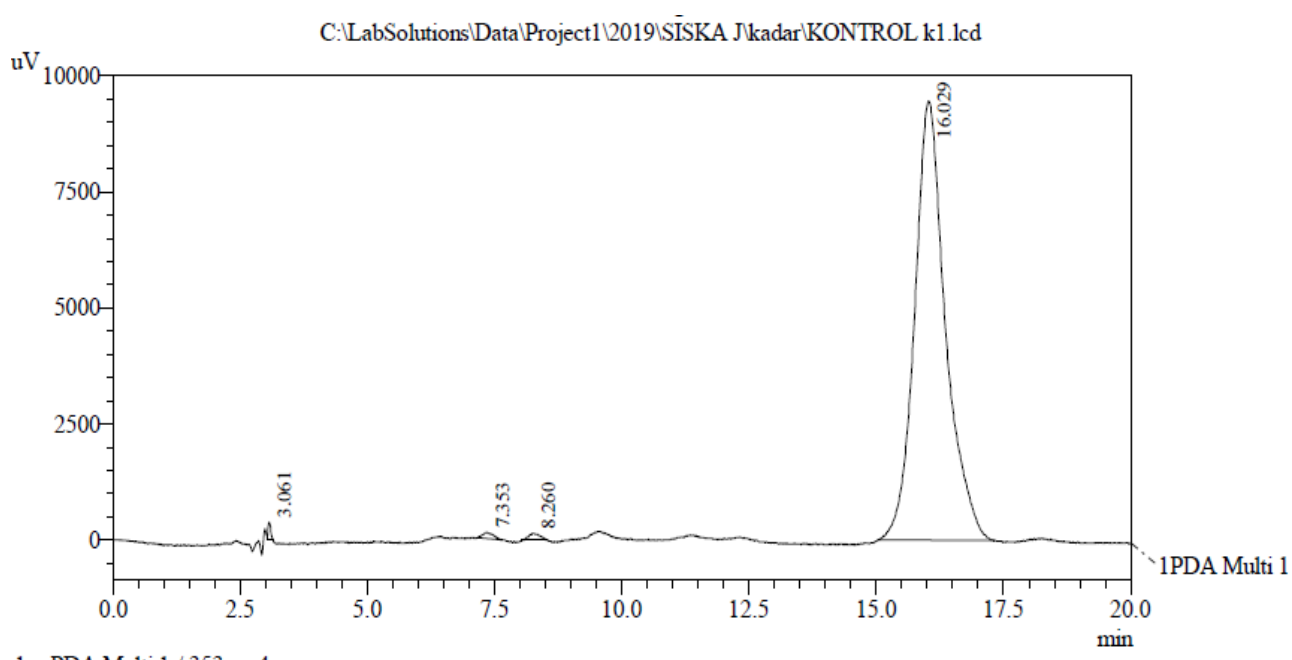

1 PDA Multi $1 / 353 \mathrm{~nm} 4 \mathrm{~nm}$

Gambar 3. Kromatogram krim 1

Tabel I. Data hasil validasi LOD dan LOQ

\begin{tabular}{|c|c|c|c|c|c|c|}
\hline \multirow{2}{*}{$\begin{array}{c}\text { Konsentrasi } \\
\text { (ppm) }\end{array}$} & \multicolumn{3}{|c|}{ luas puncak } & \multirow{2}{*}{ rata-rata $(y)$} & \multirow{2}{*}{ yi } & \multirow{2}{*}{$(y-y i) 2$} \\
\hline & I & II & III & & & \\
\hline 2 & 103025 & 106175 & 102422 & 103874 & 97313 & 43046721 \\
\hline 4 & 204140 & 202852 & 201905 & 202965,7 & 204327 & 1853137,69 \\
\hline 6 & 303092 & 300852 & 303785 & 302576,3 & 311341 & 76819966,09 \\
\hline 8 & 414077 & 416401 & 410636 & 413704,7 & 418355 & 21628080,36 \\
\hline 10 & 534879 & 533784 & 532052 & 533571,7 & 525369 & 67284287,29 \\
\hline \multicolumn{6}{|c|}{$\sum$} & 210632192,43 \\
\hline \multicolumn{6}{|c|}{$\mathrm{N}$} & 5 \\
\hline \multicolumn{6}{|c|}{ SDr } & 8379,18 \\
\hline \multicolumn{6}{|c|}{ LOD } & 0,4689 \\
\hline \multicolumn{6}{|c|}{ LOQ } & 1,565997 \\
\hline
\end{tabular}

Pada penelitian ini menggunakan validasi metoda KCKT dari senyawa asam retinoat dilakukan terhadap beberapa parameter yaitu linieritas, LOD dan LOQ, akurasi dan presisi. Limit of detection (LOD) dan limit of quantitation (LOQ) ditentukan dari persamaan regresi linier kurva kalibrasi (Tabel I). LOD ditentukan untuk mengetahui konsentrasi analit terendah yang dapat diukur dan LOQ ditentukan untuk mengetahui konsentrasi terendah yang dapat ditentukan oleh suatu metode pada tingkat ketelitian dan ketepatan yang baik (Gandjar and Rohman, 2007). 
Tabel II. Data hasil validasi presisi dan akurasi

\begin{tabular}{cccccccc}
\hline ppm & $\begin{array}{c}\text { Luas } \\
\text { Puncak }\end{array}$ & $\begin{array}{c}\text { Kadar } \\
(\mathrm{xi})\end{array}$ & $\begin{array}{c}\text { Rata-rata } \\
(\mathrm{x})\end{array}$ & $\sum(\mathrm{x}-\mathrm{xi})$ & SD & \%RSD & \%Akurasi \\
& & & & & & \\
\hline \multirow{2}{*}{2} & 103025 & 1,7441 & & & & & \\
& 106175 & 1,8030 & 1,76 & 0,00095 & 0,0218 & 1,2386 & 88 \\
& 102422 & 1,7329 & & & & & \\
& 303092 & 5,4832 & & & & & \\
6 & 300852 & 5,4414 & 5,4736 & 0,000547 & 0,0165 & 0,3014 & 91,22 \\
& 303785 & 5,4962 & & & & & \\
& 534879 & 9,8151 & & & & & \\
& 533784 & 9,795 & 9,7908 & 0,0004535 & 0,0151 & 0,48874 & 97,90 \\
& & & & & & & \\
\hline
\end{tabular}

Uji presisi dilakukan untuk uji kesesuaian sistem yang dilakukan setelah melakukan KCKT (Tabel II). Uji ini dilakukan dengan menyuntikkan berulang larutan standar asam retinoat yang diketahui konsentrasinya untuk menentukan kinerja alat. Harga relatif standar deviasi (RSD) sesuai Farmakope Indonesia edisi IV yaitu $\leq 2 \%$ (Manurung, 2015). Ketelitian metode dilakukan sebanyak 3 kali pengulangan. Dari data uji presisi menunjukkan nilai $\mathrm{RSD} \leq 2 \%$ maka metode yang digunakan dikatakan memenuhi persyaratan bahwa metode kerja sesuai dengan sistem KCKT yang digunakan dan dapat menghasilkan akurasi dan presisi yang dapat diterima.

Tabel III. Data kadar asam retinoat pada krim pemutih

\begin{tabular}{ccc}
\hline Sampel & $\begin{array}{c}\text { Konsentrasi } \\
(\mathbf{p p m})\end{array}$ & Kadar (\%) \\
\hline Krim 1 & 6 & 0,032 \\
Krim 2 & 6 & 0,015 \\
Krim 3 & 6 & 0,014 \\
Krim 4 & 6 & 0,021 \\
Krim 5 & 6 & 0,011 \\
\hline
\end{tabular}

Menurut (Badan POM RI, 2008) asam retinoat termasuk bahan yang dilarang penggunaannya sejak tahun 1998. Asam retinoat juga merupakan obat keras yang hanya boleh dibeli dengan resep dokter. Dari penelitian ini diperoleh bahwa krim 1, krim 2, krim 3,krim 4 dan krim 5 yang diambil di klinik kecantikan dan salon kota Jambi pada 
kecamatan Jelutung positif mengandung asam retinoat, yang tidak sesuai dengan persyaratan yang telah ditentukan BPOM, yaitu tentang larangan penggunaan bahan berbahaya asam rertinoat pada kosmetik yang dapat menyebabkan kulit kering, rasa terbakar, teratogenik (cacat pada janin) dan penyebab kanker kulit (Tabel III).

\section{Evaluasi krim}

Evaluasi krim pada penelitian ini dilakukan untuk mengetahui kualitas dari krim pemutih yang dijual di klinik kecantikan dan salon kota Jambi yang meliputi pengujian organoleptis, uji daya sebar, $\mathrm{pH}$ dan uji iritasi.

Dari pemeriksaan homogenitas krim dinyatakan homogen pada saat pengamatan krim mempunyai tekstur yang tampak rata, tidak menggumpal dan tidak ada butiran butiran (Pratimasari et al., 2015). Dari pemeriksaan diperoleh hasil bahwa tidak terlihat butiran-butiran partikel saat dilakukan uji homogenitas yang artinya sediaan homogen.

$\mathrm{pH}$ produk adalah faktor yang dapat digunakan sebagai indikator keamanan, krim dengan $\mathrm{pH}$ terlalu asam dapat mengiritasi kulit sedangkan krim yang terlalu basa dapat membuat kulit menjadi kering sehingga sediaan harus memiliki $\mathrm{pH}$ yang sesuai dengan kulit (Suhery et al., 2016). Menurut SNI 16-4399-1996 pH krim yang ideal adalah adalah sesuai dengan $\mathrm{pH}$ kulit, yaitu berkisar 4,5 - 8.0. Hasil pengukuran $\mathrm{pH}$ menunjukkan nilai $\mathrm{pH}$ sediaan krim pemutih tersebut berkisar 4,7 - 5,8 sehingga $\mathrm{pH}$ sediaan krim ini telah memenuhi syarat tersebut.

Iritasi pada kulit dapat disebabkan oleh beragam faktor diantaranya lama pemberian, luas area pemberian, tingkat penetrasi dan ketoksikan dari bahan yang diaplikasikan (More et al., 2013). Uji iritasi dilakukan kulit menunjukkan tidak terdapatnya iritasi yang ditimbulkan ketika kontak langsung dengan kulit (Putrinesia et al,. 2018). Hasil pengujian menunjukkan tidak adanya iritasi pada kulit, sehingga sediaan krim pemutih ini aman untuk digunakan sebagai sediaan topikal (Tabel II). 


\begin{tabular}{cccccc}
\hline \hline \multicolumn{5}{c}{ Tabel IV. Hasil evaluasi organopleptis, pH, iritasi dan stabilitas krim } \\
\hline \multirow{2}{*}{ Pengamatan } & Krim 1 & Krim 2 & Krim 3 & Krim 4 & Krim 5 \\
\hline Warna & Putih pucat & Putih pucat & Putih & Putih & $\begin{array}{c}\text { Putih } \\
\text { kekuningan }\end{array}$ \\
& & & & & Semi solid \\
Bentuk & Semi solid & Semi solid & Semi solid & Semi solid & Semi solid \\
Bau & Bau krim & Menyengat & Bau krim & Bau krim & Bau krim \\
Homogenitas & Homogen & Homogen & Homogen & Homogen & Homogen \\
pH & 4,8 & 5,2 & 5,3 & 5,4 & 5,7 \\
Iritasi & Tidak & Tidak & Tidak & Tidak & Tidak \\
& mengiritasi & mengiritasi & mengiritasi & mengiritasi & mengiritasi \\
Stabilitas & Stabil suhu & Stabil suhu & Stabil suhu & Stabil suhu & Stabil suhu \\
& $4^{\circ} \mathrm{C}$, Ruang & $4^{\circ} \mathrm{C}$, Ruang & $44^{\circ} \mathrm{C}$, Ruang & $4{ }^{\circ} \mathrm{C}$ dan & $4^{\circ} \mathrm{C}$ dan \\
& $\left(25^{\circ} \mathrm{C},\right)$ dan & $\left(25^{\circ} \mathrm{C}\right)$ dan & $\left(25^{\circ} \mathrm{C}\right)$ dan & Ruang & Ruang \\
& $40^{\circ} \mathrm{C}$ & $40^{\circ} \mathrm{C}$ & $40^{\circ} \mathrm{C}$ & $\left(25^{\circ} \mathrm{C}\right)$ & $\left(25^{\circ} \mathrm{C}\right)$ \\
\hline
\end{tabular}

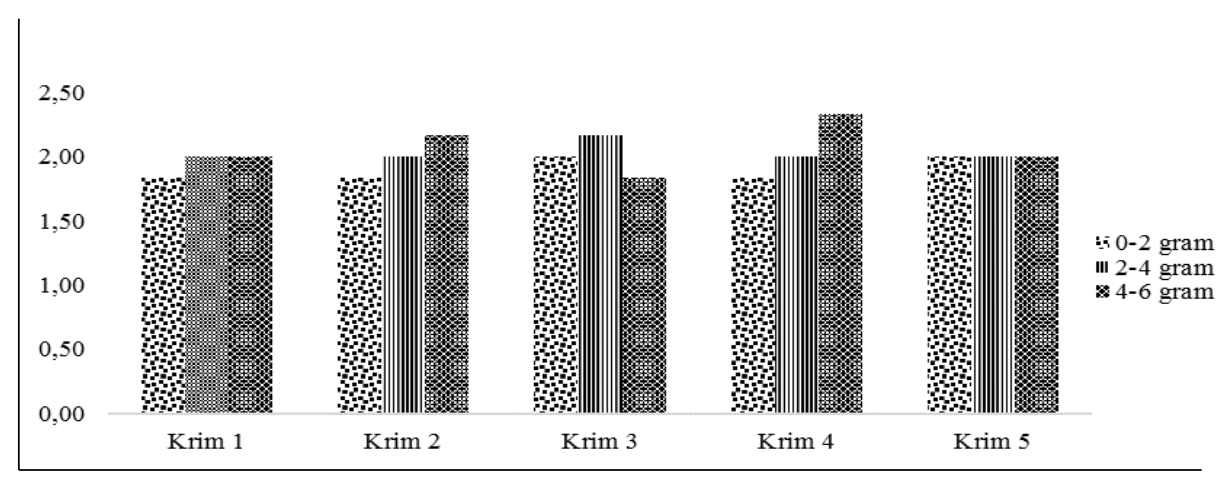

Gambar 3. Uji daya sebar krim

Hasil pengujian daya sebar masing-masing krim (Gambar 3) menunjukkan kemampuan menyebar sediaan semakin besar seiring dengan bertambahnya beban. Hal ini sesuai dengan penelitian sebelumnya (Andriana et al., 2011) yang menyatakan luas penyebaran berbanding lurus dengan kenaikan penambahan beban, semakin besar beban yang ditambahkan daya sebar yang dihasilkan semakin luas. Hal ini jika dikaitkan dengan viskositas dimana jika daya sebarnya tinggi maka viskositasnya rendah sebaliknya jika viskositasnya tinggi maka daya sebarnya rendah. Suatu sediaan akan lebih disukai apabila dapat menyebar dengan mudah di kulit, karena pemakaiannya lebih mudah dan nyaman . 
KESIMPULAN

Berdasarkan hasil penelitian menunjukkan bahwa krim 1, 2, 34 dan 5 positif mengandung senyawa asam retinoat yang tidak sesuai dengan persyaratan yang telah ditentukan BPOM, yaitu tentang larangan penggunaan bahan berbahaya asam retinoat pada kosmetik yang dapat menyebabkan kulit kering, rasa terbakar, teratogenik (cacat pada janin) dan penyebab kanker kulit. Kadar asam retinoat krim 1 (salon) sebesar 0,032 \%, pada krim 2 (klinik) sebesar 0,015\% (klinik), pada krim 3 0,014\% (klinik), pada krim 4 (klinik) 0,021\% dan pada krim 5 (klinik) 0,011\%.

\section{DAFTAR PUSTAKA}

Andriana, I., Murrukmihardi, M., \& Ekowati, D. (2011). Pengaruh Konsentrasi Tragakan terhadap Mutu Fisik Sediaan Pasta Gigi Ekstrak Etanolik Daun Mahkota Dewa (Phaleria papuana Warb var. Wichnannii) sebagai Antibakteri Streptococcus mutans. Jurnal Farmasi Indonesia, 8(1), 66-76.

Anggraeni, V. J., Yuliantini, A., Rahmawati, F., Farmakokimia, R., Tinggi, S., \& Bandung, F. (2018). Analisis Cemaran Logam Berat Merkuri dalam Krim Pemutih Wajah yang Beredar di Pasar Tradisional dengan Metode Spektrofotometri Serapan Atom. Journal of Pharmacopolium, 1(1), 44-50.

Badan POM RI. (2008). Bahan berbahaya dalam kosmetik. In: kosmetik pemutih (Whitening), naturakos, 3(8).

Gandjar, I. G., \& Rohman, A. (2007). Kimia farmasi analisis. Pustaka Pelajar.

Ismail, I., Ningsi, S., \& Tahar, N. (2014). Pengaruh Jenis Pengikat Terhadap Sifat Fsiska Sediaan Serbuk Masker Wajah Kulit Buah Semangka (Citrullus vulgaris Schrad). Jurnal Farmasi Fik Uinam, 2(2), 80-86.

Kurniasih, N. (2016). Formulasi sediaan krim tipe m/a ekstrak biji kedelai .( Glycine max L) : Uji Stabilitas Fisik Dan Efek Pada Kulit. Universitas Muhammadiyah Surakarta.

Manurung, H. (2015). Analisis fisikokimia kromotografi volume 2. Kedokteran. Jakarta.

Miller, J. N., \& Miller, J. C. (2005). Statistics and chemometrics for analytical chemistry, 5th edition, pearson education limited, edinburg gate, England.

More, B., Sakhawarde, S., Tembhurne, S., \& D.M.Sakarkar. (2013). Evaluation for skin irritacy testing of developed formulations containing extract of butea monospermafor its topical application. International Journal of Toxicology and Applied Pharmacology., 3(1), 10-13. 
Pratimasari, D., Sugihartini, N., Yuwono, T. (2015). Evaluasi sifat fisik dan uji iritasi sediaan salep minyak atsiri bunga cengkeh dalam basis larut air, Jurnal Ilmiah Farmasi., 11(1), 9-15.

Puspitasari, A. D., Andini, D., Mulangsri, K., \& Hasyim. (2018). Formulasi Krim Tabir Surya Ekstrak Etanol Daun Kersen ( Muntingia calabura L .) untuk Kesehatan Kulit, 1, 263-270.

Putrinesia, I., Pratama, Y., Tobing, L., Asikin, N., \& Rahmalia, W. (2018). Formulasi dan Uji Aktivitas Krim Pengkelat Merkuri Berbahan Dasar Ekstrak Etanol Alga Coklat ( Sargassum sp . ), 14(1), 152-163.

Rahayu, W. S., Nurulita, N. A., \& Septianingrum, D. A. (2014). Analisis asam retinoat dalam sediaan krim pemutih yang dijual bebas di wilayah Purwokerto.

Septadina, I. S. (2012). Efek Teratogenik Vitamin A Dosis Tinggi dan Senyawa Turunannya Selama Kehamilan. Proceding Book" Anatomy For A Better Quality OfLife."

Suhartini, S., Citraningtyas, G., \& Farmasi, P. S. (2013). Analisis asam retinoat pada kosmetik krim pemutih yang beredar di pasaran kota Manado. Pharmacon, 2(1), 18.

Suhery, W. N., Fernando, A., \& Has, N. (2016). Uji aktivitas antioksidan dari ekstrak bekatul padi ketan merah dan hitam (Oryza Sativa L. Var. Glutinosa) dan formulasinya dalam sediaan krim. Jurnal Pharmacy, 13(1), 101-115.

Yulianti, E., Adelsa, A., \& Putri, A. (2015). The Determination of SPF (Sun Protection Factor) Value of $70 \%$ Ethanol Extract Curcuma Mangga and $70 \%$ Ethanol Extract Curcuma Mangga Cream In Vitro using Spektrofotometry Method, 2, 4150 . 